\title{
Subendothelial Retention of Lipoprotein (a) Evidence That Reduced Heparan Sulfate Promotes Lipoprotein Binding to Subendothelial Matrix
}

Sivaram Pillarisetti, Latha Paka, Joseph C. Obunike, Lars Berglund, and Ira J. Goldberg

Division of Preventive Medicine and Department of Medicine, Columbia University College of Physicians and Surgeons, New York 10032

\begin{abstract}
Vessel wall subendothelial extracellular matrix, a dense mesh formed of collagens, fibronectin, laminin, and proteoglycans, has important roles in lipid and lipoprotein retention and cell adhesion. In atherosclerosis, vessel wall heparan sulfate proteoglycans (HSPG) are decreased and we therefore tested whether selective loss of HSPG affects lipoprotein retention. A matrix synthesized by aortic endothelial cells and a commercially available matrix (Matrigel; Becton Dickinson Inc., Rutherford, NJ) were used. Treatment of matrix with heparinase/heparitinase $(1 \mathrm{U} / \mathrm{ml}$ each) increased LDL binding by $\sim 1$.5-fold. Binding of lipoprotein (a) $[\mathrm{Lp}(\mathrm{a})]$ to both subendothelial matrix and Matrigel ${ }^{\circledR}$ increased 2-10-fold when the HSPG were removed by heparinase treatment. Incubation of endothelial cells with oxidized LDL (OxLDL) or lysolecithin resulted in decreased matrix proteoglycans and increased $L p(a)$ retention by matrix. The effect of OxLDL or lysolecithin on endothelial PG was abolished in the presence of HDL. The decrease in matrix HSPG was associated with production of a heparanase-like activity by OxLDL-stimulated endothelial cells. To test whether removal of HSPG exposes fibronectin, a candidate $\mathrm{Lp}(\mathrm{a})$ binding protein in the matrix, antifibronectin antibodies were used. The increased Lp(a) binding after HSPG removal was inhibited $60 \%$ by antifibronectin antibodies. Similarly, the increased $\mathrm{Lp}(\mathrm{a})$ binding to matrix from OxLDLtreated endothelial cells was inhibited by antifibronectin antibodies. We hypothesize that atherogenic lipoproteins stimulate endothelial cell production of heparanase. This enzyme reduces HSPG which in turn promotes $\mathrm{Lp}$ (a) retention. (J. Clin. Invest. 1997. 100:867-874.) Key words: proteoglycans - arteriosclerosis - heparin - endothelial cells • oxidized LDL
\end{abstract}

\section{Introduction}

Lipoprotein (a) $[\mathrm{Lp}(\mathrm{a})]^{1}$ is a complex lipoprotein consisting of an LDL particle and apolipoprotein (apo) (a); apo(a) is attached to apoB-100 by a disulfide linkage $(1,2)$. Apo(a) has a high degree of homology to plasminogen, a serine protease zy-

Address correspondence to Dr. Sivaram Pillarisetti, Department of Medicine, Columbia University College of Physicians and Surgeons, BB 901, 630 West 168th Street, New York, NY 10032. Phone: 212305-1584; FAX: 212-305-5384; E-mail: ps42@columbia.edu

Received for publication 3 January 1997 and accepted in revised form 15 May 1997.

J. Clin. Invest.

(c) The American Society for Clinical Investigation, Inc. 0021-9738/97/08/0867/08 \$2.00

Volume 100, Number 4, August 1997, 867-874

http://www.jci.org mogen involved in fibrinolysis, and contains multiple tandem repeats of plasminogen kringle IV-like domains. Lp(a) is a leading inherited risk factor for atherosclerosis and stroke (3-6). $\mathrm{Lp}(\mathrm{a})$ is present in human atherosclerotic plaques and the amount of $\operatorname{Lp}(\mathrm{a})$ correlates with serum $\operatorname{Lp}(\mathrm{a})$ levels $(7,8)$. When corrected for plasma levels, the deposition of $\mathrm{Lp}(\mathrm{a})$ in the arteries exceeds that of LDL. Therefore $\mathrm{Lp}(\mathrm{a})$ appears to be preferentially deposited in the plaques $(9,10)$. This may occur because $\mathrm{Lp}$ (a) binds, at least in vitro, to purified matrix proteins via both apo(a) and apoB (11-14). However, the mechanisms mediating $\mathrm{Lp}(\mathrm{a})$ retention by the arterial subendothelial matrix (SEM), the major site of $\mathrm{Lp}(\mathrm{a})$ deposition in vivo, are not known.

SEM is a dense mesh composed of proteins and proteoglycans (PG) (15). Major SEM proteins include collagens, fibronectin, laminin, and vitronectin. $\mathrm{PG}$, which constitute a significant proportion of the matrix, contain highly negatively charged glycosaminoglycans which are attached to a core protein $(16,17)$. Matrix PG contain three major classes of glycosaminoglycans: heparan sulfate (HS), chondroitin sulfate, and dermatan sulfate. The major SEM HSPG made by cultured bovine aortic endothelial cells is perlecan (18). Perlecan has a core protein of $>400 \mathrm{kD}$ to which the HS are attached at one end. The core protein has multiple domains homologous to the LDL receptor, laminin, immunoglobulin, and epidermal growth factor.

Several studies indicate that the composition and content of glycosaminoglycans change during lesion development (1923). Arterial wall chondroitin sulfate and dermatan sulfate content increase during atherogenesis. Dermatan sulfate and chondroitin sulfate have been postulated to play a role in LDL retention within the vessel wall (21). In contrast, there is a decrease in the amount of HSPG in atherosclerotic vessels (22, 23). The cause and consequences of this decrease in HSPG in vivo are not clear. In this study we show that exposure of cultured endothelial cells to oxidized LDL (OxLDL) leads to a reduction in matrix HSPG and the production of an endothelial heparanase-like activity. More $\mathrm{Lp}(\mathrm{a})$ is retained by this HS-depleted matrix.

\section{Methods}

Materials. L-lysophosphatidylcholine (lysolecithin) from bovine brain was from Sigma Chemical Co. (St. Louis, MO). L- $\left[4,5-{ }^{3} \mathrm{H}\right]$ leucine (147 $\mathrm{Ci} / \mathrm{mmol})$ and $\left[{ }^{35} \mathrm{~S}\right]$ sulfate aqueous solutions were from Amersham Corp. (Arlington Heights, IL). Heparinase and heparitinase were purchased from either Sigma Chemical Co. or Seikagaku America Inc. (Bethesda, MD). Chondroitin ABC lyase was from Seikagaku America Inc. $1 \mathrm{U}$ will form $0.1 \mu \mathrm{mol}$ of unsaturated uronic acid/h.

1. Abbreviations used in this paper: ECCM, endothelial cell conditioned medium; HSPG, heparan sulfate proteoglycans; Lp(a), lipoprotein (a); OxLDL, oxidized LDL; SEM, subendothelial matrix. 
Lipoproteins. LDL $(d<1.063), \operatorname{Lp}(\mathrm{a})(d=1.07-1.1)$, and HDL $(d=1.1-1.21)$ were isolated from fresh plasma by ultracentrifugation. In all our experiments we used Lp(a) isolated from fresh plasma in the presence of $0.01 \%$ azide, $1 \mathrm{mM}$ EDTA, and 2,500 U/ml Trasylol (aprotinin; Bayer Pharmaceutical, West Haven, CT). The data reported here were obtained from $\mathrm{Lp}$ (a) preparations obtained from two different subjects. Each of these Lp(a) on SDS-PAGE has one apoB band and two isoforms of apo(a) and contained no degradation products. The two major apo(a) isoforms in the two different $\mathrm{Lp}(\mathrm{a})$ corresponded to sizes of 26 and 31 type IV kringle units. In some experiments a commercially available, partially purified $\mathrm{Lp}(\mathrm{a})$ was used to reconfirm the data.

LDL was oxidized by dialysis against a buffer containing $10 \mu \mathrm{M}$ $\mathrm{CuSO}_{4}$ for $24 \mathrm{~h}$ at room temperature (24). The amount of oxidation was assessed by measuring thiobarbituric acid reactive substances as described (25). The thiobarbituric acid reactive substance values of OxLDL varied in the range of $16-26 \mathrm{nmol}$ of malondialdehyde equivalents/mg protein. Thus the OxLDL used was moderately oxidized (compared to extensively oxidized LDL which typically has values of 40-45 nmol malondialdehyde). LDL and Lp(a) were radioiodinated using iodine monochloride as previously described (26).

Cells. Bovine endothelial cells were isolated and cultured as described (27). The cells (5-15 passages) were grown in MEM containing 10\% FBS (GIBCO/BRL Life Technologies, Gaithersburg, MD).

$S E M$. Endothelial cells were grown in 24- or 48-well culture dishes (Falcon; Becton Dickinson, Lincoln Park, NJ). SEM was prepared as described previously (28). Briefly, confluent monolayers of endothelial cells were washed three times with PBS and incubated for $5 \mathrm{~min}$ in a solution containing $20 \mathrm{mM} \mathrm{NH}_{4} \mathrm{OH}$ and $0.1 \%$ Triton X-100 at room temperature. Detached cells were removed by washing three times with PBS followed by three times with MEM containing 3\% BSA/(MEM-BSA). This procedure has been shown to leave the intact SEM attached to the surface of the well. In some experiments a commercially available matrix, Matrige ${ }^{\circledR}$ (Becton Dickinson), was used. Matrigel, ${ }^{\circledR}$ according to the manufacturer, contains HSPG and no chondroitin sulfate PG. $1 \mathrm{ml}$ of Matrigel ${ }^{\circledR}$ was diluted to $10 \mathrm{ml}$ with MEM-BSA and used to coat plates at $37^{\circ} \mathrm{C}$ for $2 \mathrm{~h}$. For enzyme treatment SEM or Matrige ${ }^{\circledR}$ was incubated with a mixture of heparinase and heparitinase $(1 \mathrm{U} / \mathrm{ml}$ each) or chondroitinase $(1-2 \mathrm{U} / \mathrm{ml})$ for $2 \mathrm{~h}$ at $37^{\circ} \mathrm{C}$.

In separate experiments to determine if these enzymes are active, SEM PG were metabolically labeled with ${ }^{35} \mathrm{SO}_{4}$ (see below) and incubated with heparinase/heparitinase or chondroitinase. SEM predominantly contains HSPG and $\sim 70 \%$ of total sulfate label was released by heparinase/heparitinase treatment. Heparinase and chondroitinase at the concentrations used have no significant protease activity.

Lipoprotein binding. SEM or Matrigel ${ }^{\circledR}$ was washed and incubated for $1 \mathrm{~h}$ at $37^{\circ} \mathrm{C}$ with ${ }^{125} \mathrm{I}-\mathrm{LDL}$ or Lp(a) in MEM-BSA. Unbound lipoproteins were removed, the wells were washed three times, and bound radioactivity was extracted by incubation in $0.1 \mathrm{~N} \mathrm{NaOH} / 0.1 \%$ SDS for $1 \mathrm{~h}$. For enzyme treatment SEM or Matrigel ${ }^{\circledR}$ was first treated with heparinase or chondroitinase for $2 \mathrm{~h}$ at $37^{\circ} \mathrm{C}$ washed, and lipoprotein binding was performed. In some experiments $\mathrm{Lp}(\mathrm{a})$ was first mixed with heparin ( 25 or $100 \mathrm{U} / \mathrm{ml}$, Elkins-Sinn, Cherry Hill, $\mathrm{NJ}$ ) and then added to heparinase-treated matrix.

Metabolic labeling. Endothelial PG were radiolabeled with [ $\left.{ }^{35} \mathrm{~S}\right]$ sulfate for 24-48 h (29). Cell associated PG were assessed by removing cells with $\mathrm{NH}_{4} \mathrm{OH} /$ Triton $\mathrm{X}-100$ as described above. SEM PG were extracted by incubation with $6 \mathrm{M}$ guanidine hydrochloride for $4 \mathrm{~h}$. Alternatively, SEM was incubated with heparinase/heparitinase and released radioactivity was measured to assess HS. Total endothelial cell proteins were labeled by incubating cells with $\left[{ }^{3} \mathrm{H}\right]$ leucine for $2 \mathrm{~h}$ at $37^{\circ} \mathrm{C}$. Unincorporated radioactive amino acid was removed and total protein synthesis was assessed either by extraction of cells with $0.1 \mathrm{~N}$ $\mathrm{NaOH} / 0.1 \%$ SDS for $1 \mathrm{~h}$ or by precipitation with $10 \%$ trichloroacetic acid.

To study effects of lipoproteins, endothelial cell PG were labeled as above and then incubated in MEM-BSA containing LDL, OxLDL,
HDL, or lysolecithin for $16 \mathrm{~h}$. Cell and matrix PG were assessed as above. To determine cytotoxic effects of OxLDL and lysolecithin, total protein synthesis was assessed as described above. OxLDL or lysolecithin treatment did not affect total protein synthesis. In addition there were no visible morphological changes or cell death (Trypan blue exclusion).

Measurement of HSPG-degrading activity of endothelial cell conditioned medium (ECCM). Confluent monolayers of endothelial cells were incubated for $16 \mathrm{~h}$ in MEM-BSA or MEM-BSA containing $50 \mu \mathrm{g} / \mathrm{ml} \mathrm{OxLDL}$ or $50 \mu \mathrm{M}$ lysolecithin. Subsequently, ECCM was collected and filtered. Endothelial cell monolayers and SEM in 48well culture plates were labeled with $\left[{ }^{3} \mathrm{H}\right]$ leucine or ${ }^{35} \mathrm{SO}_{4}$. Labeled cells and SEM were incubated with ECCM prepared from control and lysolecithin-treated cells for $4 \mathrm{~h}$ at $37^{\circ} \mathrm{C}$ and released label was counted. Release of $\left[{ }^{3} \mathrm{H}\right]$ leucine represents protease activity in ECCM and release of ${ }^{35} \mathrm{SO}_{4}$ represents heparanase activity.

\section{Results}

Removal of HS increases lipoprotein binding to matrix. To test whether removal of PG affects lipoprotein binding to matrix, ${ }^{125} \mathrm{I}$-LDL and $\mathrm{Lp}$ (a) binding to normal and PG-deficient matrix was assessed. Treatment with chondroitin ABC lyase (denoted C'ase), which removes both chondroitin sulfate and dermatan sulfate, did not affect the binding of either LDL or Lp(a) to SEM (Fig. $1 A$ ). In contrast, removal of HS with heparinase/ heparitinase treatment (denoted H'ase) increased LDL binding by $55 \%$ and Lp(a) binding by $200 \%$. Since the amount of PG made and deposited into SEM by endothelial cells varies, an increase of as much as 10-fold in $\mathrm{Lp}$ (a) binding was observed in some experiments. In subsequent experiments only the binding of $\mathrm{Lp}(\mathrm{a})$ to matrix was explored.

We next assessed Lp(a) binding to Matrigel ${ }^{\circledR}$. Since Matrigel $^{\circledR}$ contains only HSPG, the effects of heparinase/heparitinase were assessed. Lp(a) binding to Matrige ${ }^{\circledR}$ increased more than ninefold after the Matrige ${ }^{\circledR}$ was treated with heparinase (Fig. $1 \mathrm{~B}$ ). These data suggest that matrix HS inhibit lipoprotein interaction with matrix. Surprisingly, the increased Lp(a) binding resulting from heparinase treatment of Matrige ${ }^{\circledR}$ was not inhibited by exogenous heparin $(25 \mathrm{U} / \mathrm{ml})$. This suggests that heparin does not interact with matrix proteins in the same fashion as native HSPG.

OxLDL and lysolecithin decrease SEM PG. We previously reported (29) that endothelial cells exposed to lysolecithin produce an HSPG-degrading heparanase-like activity and we postulated that this activity decreases SEM HSPG. Since lysolecithin is a component of OxLDL, we tested whether OxLDL treatment alters SEM HSPG and leads to increased Lp(a) binding to SEM. Endothelial cells containing ${ }^{35} \mathrm{SO}_{4}$-labeled PG were incubated with $100 \mu \mathrm{g} / \mathrm{ml}$ LDL, 25-100 $\mu \mathrm{g} / \mathrm{ml}$ OxLDL, or $50 \mu \mathrm{M}$ lysolecithin for $16 \mathrm{~h}$ and SEM PG were determined by extraction with $6 \mathrm{M}$ guanidine hydrochloride (Fig. 2 $A$ ). As we previously reported (29), LDL treatment did not affect the amount of PG in SEM. OxLDL in a dose-dependent fashion decreased SEM PG. At $100 \mu \mathrm{g} / \mathrm{ml}$, OxLDL reduced the amount of PG in the SEM by $>70 \%$. As expected, lysolecithin decreased SEM PG by $\sim 50 \%$. Lysolecithin (29) and OxLDL at these concentrations did not affect total protein synthesis $\left(\left[{ }^{3} \mathrm{H}\right] \mathrm{leucine}\right.$ incorporation into proteins) suggesting the absence of cytotoxic effects.

Decreased HSPG in matrix could be due to decreased synthesis or increased degradation. We previously showed an HSPG-degrading heparanase-like activity in lysolecithin-stim- 
A

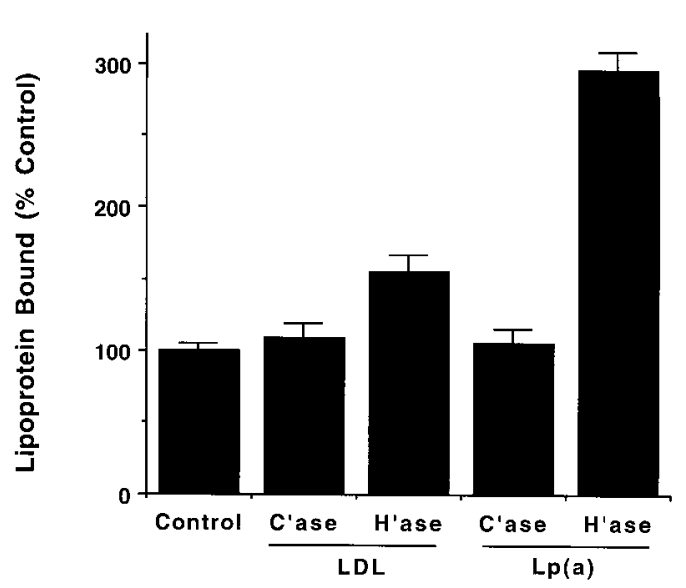

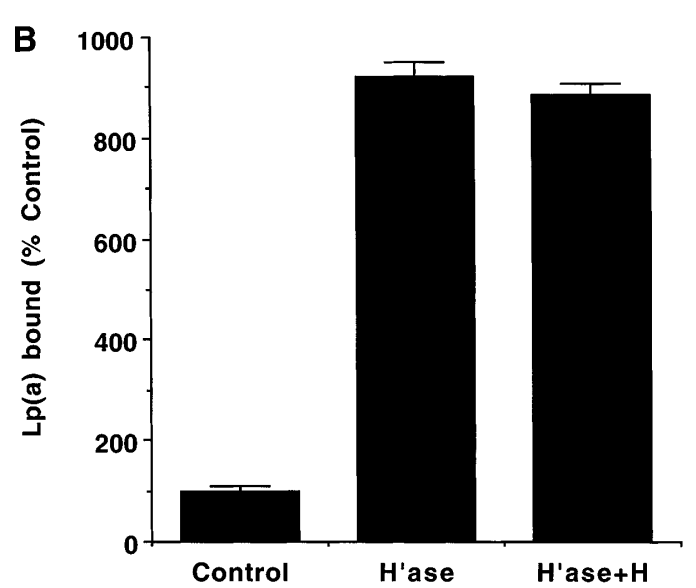

Figure 1. (A) Removal of HS increases lipoprotein binding to SEM. SEM was prepared as described and incubated in MEM-BSA (Control) or MEM-BSA containing $1 \mathrm{U} / \mathrm{ml}$ of chondroitin ABC lyase (C'ase) or $1 \mathrm{U} / \mathrm{ml}$ each of heparinase and heparitinase $\left(H^{\prime}\right.$ ase) for $2 \mathrm{~h}$ at $37^{\circ} \mathrm{C} .{ }^{125} \mathrm{I}-\mathrm{LDL}$ or $\mathrm{Lp}$ (a) was added and incubated for $1 \mathrm{~h}$ at $37^{\circ} \mathrm{C}$. Bound lipoproteins were determined by extraction with $\mathrm{NaOH} / \mathrm{SDS}$ as described. Values represent average of triplicate experiments $\pm \mathrm{SD}, 100 \%$ equals $10 \pm 1.5 \mathrm{ng}$ for $\mathrm{LDL}$ and $7.4 \pm 0.9 \mathrm{ng}$ for $\mathrm{Lp}(\mathrm{a})$. (B) $\mathrm{Lp}(\mathrm{a})$ binding to Matrigel ${ }^{\circledR}$ is increased by removal of HS. Matrigel ${ }^{\circledR}$ was diluted sixfold with MEM-BSA and used to coat 24-well plates for $2 \mathrm{~h}$ at $37^{\circ} \mathrm{C}$. Wells were then incubated with MEM-BSA (Control) or MEM-BSA containing $1 \mathrm{U} / \mathrm{ml}$ heparinase and heparitinase (H'ase) for $2 \mathrm{~h}$ at $37^{\circ} \mathrm{C}$. Wells were washed and incubated with ${ }^{125} \mathrm{I}-\mathrm{Lp}(\mathrm{a})$ for $1 \mathrm{~h}$ at $37^{\circ} \mathrm{C}$. Bound radioactivity was determined as above. $100 \%$ equals $10.5 \pm 1.1 \mathrm{ng}$. For heparin experiment, $\mathrm{Lp}(\mathrm{a})$ was added together with $25 \mathrm{U} / \mathrm{ml}$ heparin to heparinase-treated Matrigel ${ }^{\circledR}$ and bound $\mathrm{Lp}(\mathrm{a})$ was determined.

ulated endothelial cells (29). To test whether OxLDL-mediated decrease in matrix HSPG was due to degradation of HSPG by endothelial heparanase, heparanase activity in ECCM from control and OxLDL-(OxLECCM) stimulated endothelial cells was determined (Fig. $2 \mathrm{~B}$ ). 2.4-fold more $\left[{ }^{35} \mathrm{~S}\right]$ sulfate was released from $\left[{ }^{35} \mathrm{~S}\right]$ HSPG-containing matrix by OxLECCM, suggesting that endothelial cells secrete a heparanase-like activity in response to OxLDL. OxLDL did not release radiolabel from $\left[{ }^{3} \mathrm{H}\right]$ leucine-labeled SEM, suggesting the absence of protease-like activity.

HDL blocks OxLDL and lysolecithin effects on SEM PG. Since HDL inhibits several effects of OxLDL, we tested whether the OxLDL- and lysolecithin-mediated decreases in SEM PG were inhibited by HDL. Incubation of cells with

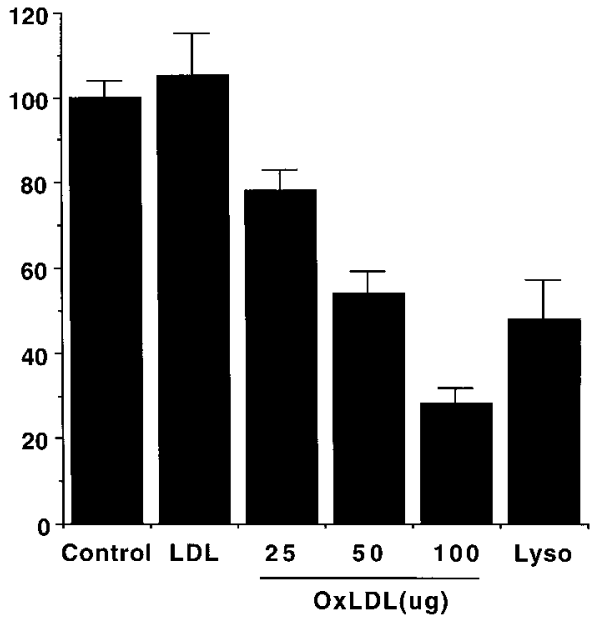

B

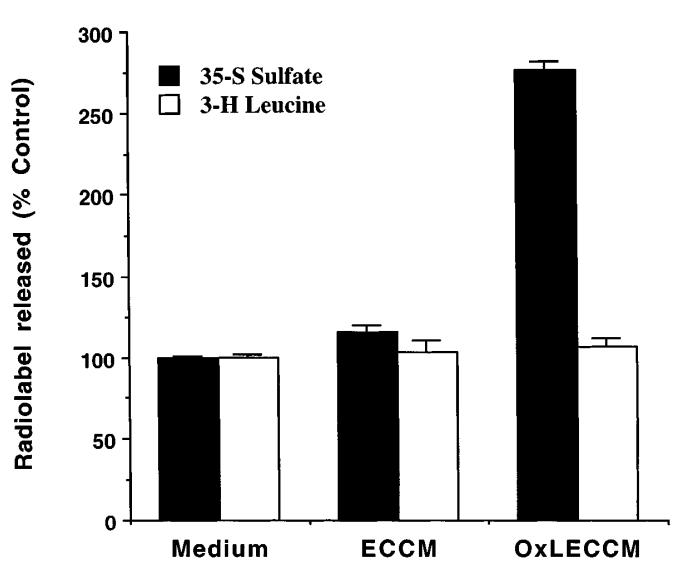

Figure 2. (A) OxLDL and lysolecithin decrease matrix proteoglycans. Endothelial cell proteoglycans were metabolically labeled with ${ }^{35} \mathrm{SO}_{4}$ by incubation in ${ }^{35} \mathrm{SO}_{4}$-containing medium for $48 \mathrm{~h}$. Medium was removed and the cells were washed with MEM-BSA and incubated with MEM alone (Control) or MEM containing $100 \mu \mathrm{g} / \mathrm{ml} \mathrm{LDL}$, different concentrations of OxLDL, or $50 \mu \mathrm{M}$ lysolecithin for $16 \mathrm{~h}$ at $37^{\circ} \mathrm{C}$. After treatments, media were removed and SEM was prepared as described in Methods. Total matrix proteoglycans were determined by extraction for $4 \mathrm{~h}$ with $6 \mathrm{M}$ guanidine hydrochloride. OxLDL decreased matrix proteoglycans in a dose-dependent manner. (B) OxLDL-stimulated endothelial cells secrete a heparanase-like activity. Endothelial cells were incubated with MEM-BSA or MEM-BSA containing $100 \mu \mathrm{g} / \mathrm{ml}$ OxLDL for $16 \mathrm{~h}$ and ECCM was collected. Endothelial PG were metabolically labeled with ${ }^{35} \mathrm{SO}_{4}$ by incubation in ${ }^{35} \mathrm{SO}_{4}$-containing medium for $48 \mathrm{~h}$ and $\mathrm{SEM}$ was prepared. Total proteins were metabolically labeled by incubation in medium containing $25 \mu \mathrm{Ci} / \mathrm{ml}\left[{ }^{3} \mathrm{H}\right]$ leucine for $16 \mathrm{~h}$. SEM containing labeled HSPG or proteins were incubated with MEM-BSA, ECCM, or OxLECCM for $4 \mathrm{~h}$ at $37^{\circ} \mathrm{C}$. Released label was counted. Approximately 2.6-fold more ${ }^{35} \mathrm{~S}$ label was released by OxLECCM, suggesting the presence of an HSPG-degrading activity. OxLECCM did not release [ $\left.{ }^{3} \mathrm{H}\right]$ leucine suggesting the absence of protease-like activity. 


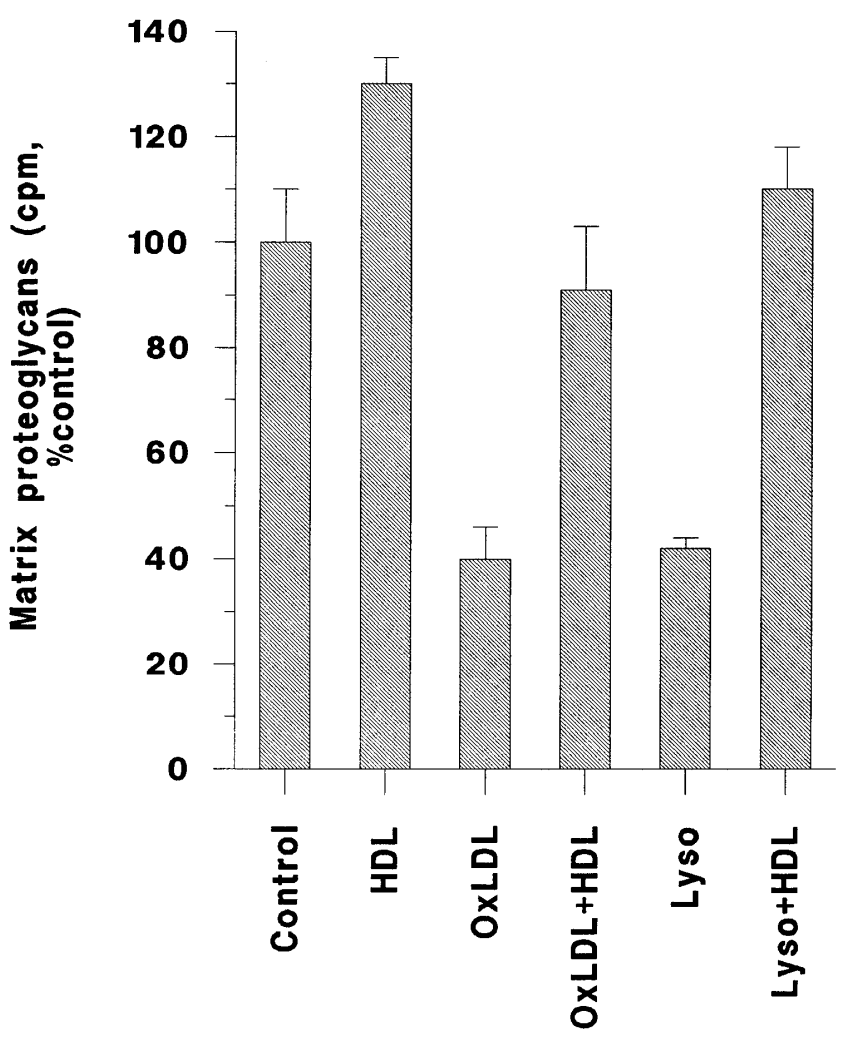

Figure 3. HDL abolishes OxLDL and lysolecithin effects on SEM PG. Endothelial cell proteoglycans were metabolically labeled with ${ }^{35} \mathrm{SO}_{4}$ by incubation in ${ }^{35} \mathrm{SO}_{4}$-containing medium for $48 \mathrm{~h}$. Medium was removed and the cells were washed with MEM-BSA and incubated with MEM alone (Control) or MEM containing $100 \mu \mathrm{g} / \mathrm{ml}$ HDL, $100 \mu \mathrm{g} / \mathrm{ml}$ OxLDL, $50 \mu \mathrm{M}$ lysolecithin, $100 \mu \mathrm{g} / \mathrm{ml}$ each of OxLDL and HDL, and $50 \mu \mathrm{M}$ lysolecithin $+100 \mu \mathrm{g}$ HDL for $16 \mathrm{~h}$ at $37^{\circ} \mathrm{C}$. After treatments, media were removed and SEM was prepared as described in Methods. Total SEM proteoglycans were determined by extraction for $4 \mathrm{~h}$ with $6 \mathrm{M}$ guanidine hydrochloride.

HDL alone $(100 \mu \mathrm{g} / \mathrm{ml})$ slightly increased the amount of PG in cells by $21 \%$ (not shown) and in SEM by $25 \%$ (Fig. 3 ). OxLDL $(100 \mu \mathrm{g} / \mathrm{ml})$ and lysolecithin $(50 \mu \mathrm{M})$ in this experiment decreased SEM PG by 61 and 56\%, respectively. These decreases in SEM HSPG caused by OxLDL or lysolecithin treatment were completely abolished when the incubation was performed in the presence of HDL $(100 \mu \mathrm{g} / \mathrm{ml})$.

OxLDL or lysolecithin treatment of endothelial cells increases $L p(a)$ binding to $S E M$. We next tested whether the OxLDL-mediated decrease in HSPG increases Lp(a) binding to SEM. ${ }^{125} \mathrm{I}-\mathrm{Lp}$ (a) binding to SEM prepared from control and lipoprotein-treated cells was assessed (Fig. 4). Similar amounts of $\mathrm{Lp}(\mathrm{a})$ bound to matrix prepared from control cells and LDL-treated cells. Lp(a) binding to SEM prepared from OxLDL-treated endothelial cells increased to $\sim 260 \%$ of control. Similarly, SEM prepared from lysolecithin-treated cells also bound more $\mathrm{Lp}(\mathrm{a})$. These data show that the reduction in HSPG caused by OxLDL and lysolecithin treatment allows more $\mathrm{Lp}(\mathrm{a})$ binding.

HS mask Lp(a) binding sites in the matrix. We hypothesized that removal of HS exposed Lp(a) binding sites in the matrix. We therefore tested whether an $\mathrm{Lp}(\mathrm{a})$ binding protein

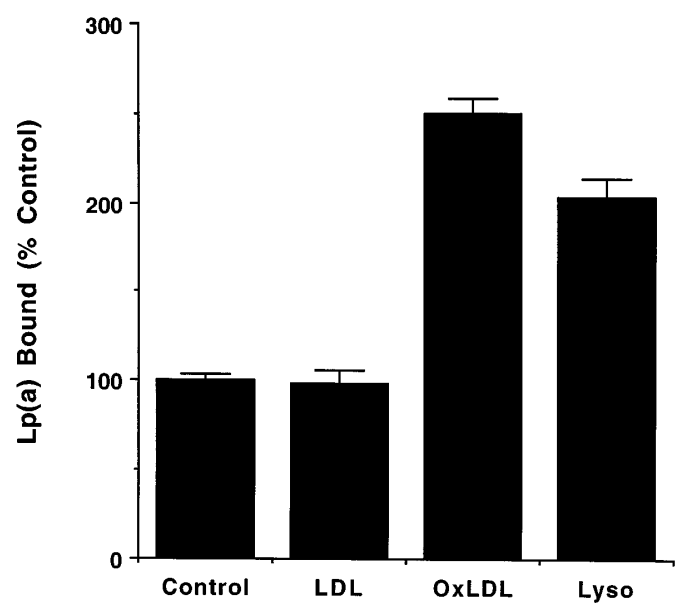

Figure 4. Matrix prepared from OxLDL- and lysolecithin-treated cells binds more Lp(a). Endothelial cells were treated with LDL, OxLDL, or lysolecithin as described in Fig. 2. SEM was then prepared from control and lipoprotein-treated cells and ${ }^{125} \mathrm{I}-\mathrm{Lp}$ (a) binding was assessed. The amount of $\mathrm{Lp}(\mathrm{a})$ bound to control matrix was $11 \pm 0.9$ ng. Approximately 2.5- and 2-fold more Lp(a) was bound, respectively, to SEM prepared from OxLDL and lysolecithin-treated endothelial cells.

such as fibronectin was exposed after heparinase treatment. SEM was treated with heparinase/heparitinase for $2 \mathrm{~h}$ at $37^{\circ} \mathrm{C}$ and then incubated with fibronectin antibodies for $30 \mathrm{~min}$ before the addition of $\mathrm{Lp}$ (a) (Fig. 5). Heparinase in this experiment increased $\mathrm{Lp}(\mathrm{a})$ binding by twofold. Fibronectin antibodies (AntiFN) inhibited Lp(a) binding to heparinase-treated, but not to control, SEM by $60 \%$. Similarly, fibronectin antibodies also decreased the amount of $\operatorname{Lp}(\mathrm{a})$ bound to heparinasetreated Matrigel ${ }^{\circledR}$ by $\sim 40 \%(65.5 \pm 7$ vs. $41 \pm 3 \mathrm{ng})$.

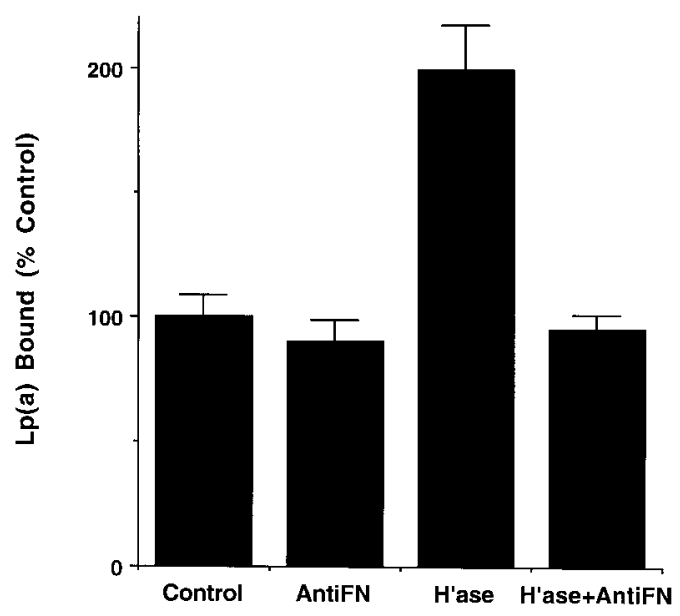

Figure 5. Removal of HS exposes Lp(a) binding sites on matrix fibronectin. SEM was incubated with MEM-BSA (Control) or MEMBSA containing $1 \mathrm{U} / \mathrm{ml}$ each of heparinase and heparitinase (H'ase) for $2 \mathrm{~h}$ at $37^{\circ} \mathrm{C}$. Polyclonal fibronectin antibodies (Sigma Chemical Co., 1:100 dilution) were then added to control (AntiFN) and heparanase-treated matrix (H'ase $+A n t i F N)$ and further incubated for $30 \mathrm{~min}$ at $37^{\circ} \mathrm{C} .{ }^{125} \mathrm{I}-\mathrm{Lp}$ (a) binding was determined as described above. The increase in $\mathrm{Lp}(\mathrm{a})$ binding resulting from H'ase treatment was inhibited by fibronectin antibodies. 


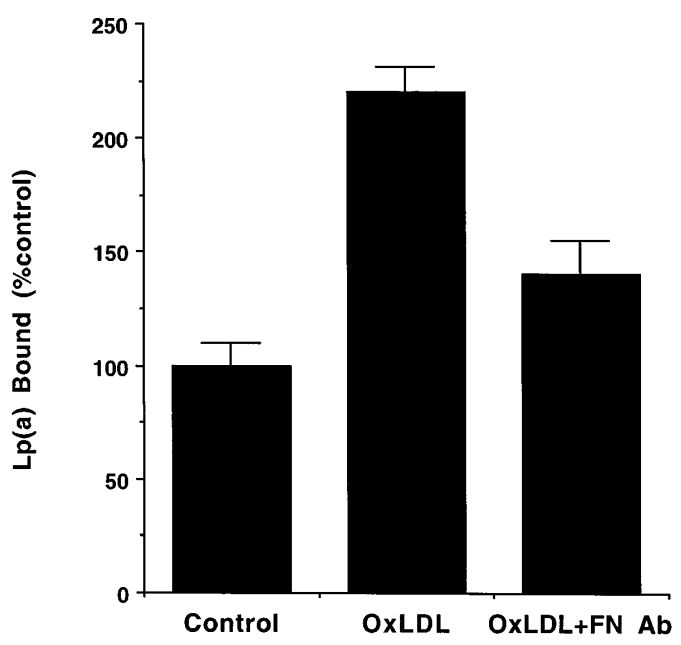

Figure 6. Lp(a) binding to SEM from OxLDL-treated endothelial cells is decreased by antifibronectin antibodies. Endothelial cells were treated with OxLDL as described in Fig. 3. Lp(a) binding to control and OxLDL matrix was assessed in the absence or presence of fibronectin antibodies $(F N A b)$ as described in Fig. 4. The increase in $\mathrm{Lp}$ (a) binding resulting from OxLDL treatment of endothelial cells was inhibited $(\sim 58 \%)$ by fibronectin antibodies.

We next tested whether the increase in $\mathrm{Lp}(\mathrm{a})$ binding to SEM from OxLDL-treated cells was also due to exposed fibronectin. As shown in Fig. 6, OxLDL treatment of endothelial cells increased matrix binding of $\mathrm{Lp}(\mathrm{a})$ by 2.2 -fold. This was inhibited by $>60 \%$ by fibronectin antibodies. These data suggest that the OxLDL-mediated reduction in SEM HS exposes Lp(a) binding sites in SEM fibronectin.

\section{Discussion}

Subendothelial extracellular retention of lipoproteins is thought to be a crucial event in the development of fatty streaks (3032). Carew and Schwenke (33) demonstrated that lipoprotein retention, and not vessel permeability, was associated with atherosclerosis development in areas of the rabbit aorta. Ultrarapid freezing and freeze etching studies by Frank and Fogelman (34) showed that the subendothelial space of aortas from cholesterol fed rabbits has a three dimensional network of fibers and fibrils. When LDL was injected into rabbits, it rapidly crossed the intact endothelium and was trapped in this network. More recent studies from the same group showed that LDL associates with collagen fibers in the vicinity of cross connecting fibrils (35).

Much of the retention of $\mathrm{Lp}(\mathrm{a})$ within arteries appears to be due to its apo(a) component and thus differs from LDL retention which is thought to involve apoB. Although LDL are smaller diameter particles which should more easily traverse the endothelial barrier, $\mathrm{Lp}$ (a) accumulates more at atherosclerosis-prone sites (10). In cerebral vessels, most of the $\mathrm{Lp}(\mathrm{a})$ deposition is in endothelial and subendothelial layers (36). Whether molecular changes in endothelium and subendothelial matrix promote lipoprotein retention is unknown. Data presented in this manuscript suggest that loss of HSPG in the vessel may be an important contributor to increased lipoprotein retention. Removal of HS increased both LDL and Lp(a) binding. Thus, the presence of HSPG may be beneficial for the artery because it prevents retention of several atherogenic lipoproteins in the matrix.

Several investigators in the past 20 years studied glycosaminoglycans in normal and atherosclerotic vessels (20-23). Although there are variations, the major conclusion from these studies is that the contents of chondroitin sulfate and dermatan sulfate are increased in lesions while that of HS is decreased. Hollmann et al. (22) showed an inverse correlation between the amount of cholesterol in the lesion and concentration of HS in human aortas. More importantly, this negative correlation was observed both in normal and atherosclerotic vessels. Four- to five-fold more cholesterol was found in vessels which have a $50 \%$ reduction in HS content. Although the reasons for this correlation were not explained, the observation that HS inhibits lipoprotein binding to matrix provides one mechanism by which cholesterol can be deposited at regions lacking HSPG.

The mechanism of arterial HSPG decrease in vivo is unknown. This could occur due to either decreased synthesis or increased degradation. Heparanases, which degrade HSPG, have been isolated and characterized from several mammalian cells (37). This and previous (29) studies show that stimulated endothelial cells can produce such an activity. Treatment of endothelial cells with OxLDL or its component lysolecithin reduced matrix HSPG. This decrease was associated with endothelial production of a heparanase-like activity (29), suggesting that the HS decrease was more likely due to increased degradation than decreased synthesis. Matrix-degrading metalloproteases are found in atherosclerotic vessels and are synthesized by lesion macrophages $(38,39)$ and these enzymes are implicated in extracellular matrix remodeling during atherogenesis. Although such proteases could alter proteoglycans, our data are most consistent with the production of a heparanase-like activity by lysolecithin-stimulated endothelial cells. The amount of sulfate-labeled proteins, predominantly proteoglycans, was decreased in the matrix but not in the cells after lysolecithin treatment (29). This was associated with the presence in lysoand OxLECCM of an activity which released sulfate but not labeled amino acids from the matrix. Furthermore, we have previously shown that the HSPG-degrading activity was inhibited by heparin, a known heparanase inhibitor, and the ${ }^{35} \mathrm{SO}_{4}$ degradation products were similar to those released by heparinase (29). Conceivably, OxLDL could alter other matrix components apart from decreasing HSPG which results in an increase in $\mathrm{Lp}(\mathrm{a})$ binding. However, at this point we believe that the decrease observed in HSPG is sufficient to account for the increased $\mathrm{Lp}(\mathrm{a})$ binding to the matrix.

A decrease in matrix HSPG has been previously observed for endothelial cells subjected to different treatments. Guretzki et al. (40) noted that incubation of endothelial cells with high concentrations of LDL for $48 \mathrm{~h}$ caused a $50 \%$ decrease in matrix HSPG. However, it is conceivable that the LDL underwent oxidation during the long course of incubation leading to the generation of products such as lysolecithin. Other agents which affect endothelial HSPG include lipopolysaccharide (41), high glucose (42), shear stress (43), heparin (44), certain FFA (45), and activated T lymphocytes (46). Thus, a decrease in HS may be a general inflammatory reaction contributing to, among other things, increased lipoprotein binding.

The mechanisms of lysolecithin and OxLDL actions are not clear. It should be noted that the effects of lysolecithin and OxLDL in this and previous studies were observed in the pres- 
ence of $3 \%$ albumin or $10 \%$ serum, suggesting that such effects are possible in vivo in the environment of the subendothelial intima. Moreover, we found no changes in total cell protein synthesis suggesting that lysolecithin and OxLDL at the concentrations used have no cytotoxic effects. Several studies have shown that alterations in endothelial function are mediated by activation of protein kinase $C(47,48)$. Preliminary experiments showed that treatment with PMA, a known PKC activator, resulted in a decrease in matrix HSPG (not shown). Thus, it appears that PKC activation may be a required step in the secretion of heparanase. It is not known whether the endothelial heparanase is a product of new gene transcription or secreted from an existing intracellular source. Treatment of endothelial cells with lysolecithin in the presence of actinomycin D (an inhibitor of RNA synthesis, $5 \mu \mathrm{g} / \mathrm{ml}$ ) or cyclohexamide (an inhibitor of protein synthesis, $40 \mu \mathrm{g} / \mathrm{ml}$ ) completely abolished lysolecithin effects on matrix HSPG. Although this does not prove that heparanase itself is a product of new transcription, it suggests that new transcription and translation are required for heparanase secretion by endothelial cells.

In our experiments HDL completely abolished the effects of both OxLDL and lysolecithin on endothelial HSPG metabolism. The mechanism of HDL inhibition of OxLDL and lysolecithin effects is not clear. HDL might act as a sink for lysolecithin and other modified lipids preventing their actions on endothelial cells. In addition, recent studies showed that platelet activating factor acetyl hydrolase and paraoxonase enzymes associated with HDL can metabolize and reduce the content of biologically active oxidized lipids in OxLDL $(49,50)$. In our experiments, HDL alone increased both cellular and subendothelial PG. The extent of stimulation by HDL varied with different batches of HDL; an increase of $25-75 \%$ in both cell and matrix PG was observed. Thus our data show another potentially antiatherogenic effect of HDL, that it increases matrix HSPG and abolishes the effects of OxLDL on matrix HSPG.

Although the exact mechanism of increased Lp(a) binding after HS removal is not known, our data suggest that this is most likely due to unmasking of lipoprotein binding sites in the matrix proteins. Although matrix contains several adhesion proteins, of particular relevance to atherosclerosis are fibronectin and collagen type IV (51-54), and our data suggest that fibronectin may play an important role in the retention of $\mathrm{Lp}(\mathrm{a})$. Fibronectins are a class of glycoproteins found in soluble form in plasma and in an insoluble form in extracellular matrix (55). Immunohistological studies using human aortas showed a membranelike layer positive for fibronectin along the endothelium. Fibronectin is an early marker of atherogenesis and colocalizes with $\mathrm{Lp}(\mathrm{a})$ in early atherosclerotic lesions and plaques. Thus, fibronectin is a likely binding site for $\mathrm{Lp}(\mathrm{a})$ in vivo. Because HSPG are in a network with fibronectin and other matrix adhesion proteins which have HS binding domains, it is possible that removal of HS leads to exposure of those sites. Alternatively, since apo(a) is a negatively charged protein, removal of negatively charged HS in the matrix may decrease charge repulsion, leading to increased binding.

Recent studies showed that fibronectin binds to plasminogen, Lp(a), and recombinant apo(a) via its heparin binding domain and the lysine binding sites of plasminogen and apo(a) $(13,56,57)$. However, it is not clear whether heparin and $\mathrm{Lp}(\mathrm{a})$ bind to exactly the same stretch of amino acids in fibronectin. This may seem unlikely because in our experiments heparin failed to inhibit $\mathrm{Lp}$ (a) binding to heparinase-treated matrix. There may be several possibilities for the absence of heparin inhibition on $\mathrm{Lp}(\mathrm{a})$ binding. The predominant HSPG in subendothelial matrix is perlecan, which has three HS chains of molecular mass $70-100 \mathrm{kD}$ (18). If these chains are involved in binding to fibronectin, removal of these chains by heparinase treatment would presumably expose other areas in addition to the heparin-binding domains. In this scenario, one would have to assume that the HSPG blocking of $\mathrm{Lp}(\mathrm{a})$ binding may be more of a steric effect, and heparin, which has a molecular mass of only $7-10 \mathrm{kD}$ lacks such a steric effect. A second possibility may have to do with glycosaminoglycan sequence specificity. Many heparin-binding proteins bind to specific sequences in heparin/heparan sulfate. A specific sequence in perlecan HS may be involved in binding to fibronectin or other matrix proteins, and heparin, which is a heterogeneous population of glycosaminoglycans, may have limited amounts of this sequence. A third possibility is that after removal of HSPG from matrix, the matrix may reorganize (conformational change) leading to masking of the heparin-binding domain and exposing the Lp(a) binding site. Thus heparin-binding domains would no longer be available for interaction with exogenous heparin.

In our experiments, a part of the $\mathrm{Lp}$ (a) binding to heparinase-treated matrix was not inhibited by fibronectin antibodies. Other matrix proteins which can potentially bind $\mathrm{Lp}(\mathrm{a})$ include collagens, laminin, and vitronectin. Laminin, also a heparin-binding protein, has been shown to bind $\operatorname{Lp}(\mathrm{a})$ and is present in both subendothelial matrix and Matrigel (58). However, in our experiments neither laminin antibodies nor antibodies to collagen type I and IV inhibited Lp(a) binding to matrix (not shown). In addition, since $\mathrm{Lp}(\mathrm{a})$ also contains apoB, the nonfibronectin-binding could involve apoB interactions with several other matrix components, e.g., collagens or HSPG core proteins which contain lipoprotein binding sites.

\section{$L p(a)$ retention in the subendothelial matrix}

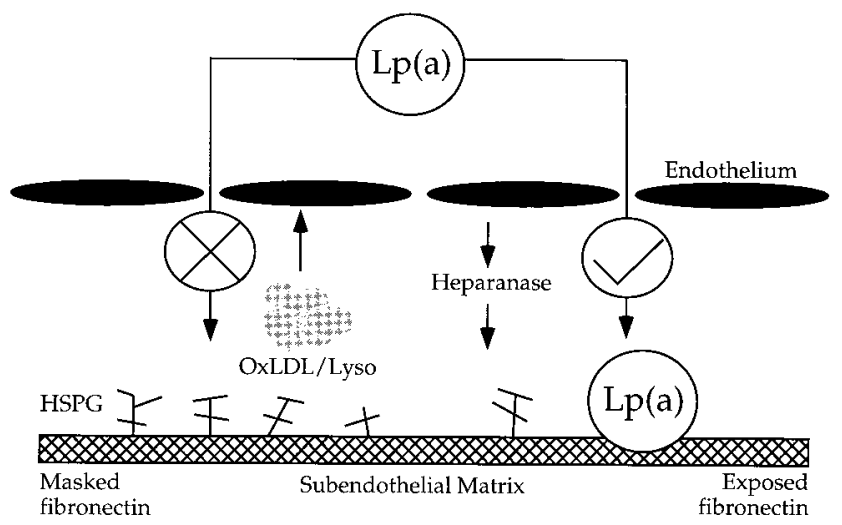

Figure 7. A model for lipoprotein (a) retention in subendothelial matrix. Some Lp(a) circulating in the bloodstream normally crosses the endothelial cell barrier. Most of this $\mathrm{Lp}(\mathrm{a})$ is not retained in the subendothelial matrix, in part because the $\mathrm{Lp}$ (a) binding sites on fibronectin are masked by HSPG. However, when, endothelial cells are stimulated by OxLDL or lysolecithin they produce a heparanase that degrades the HSPG. The loss of HSPG exposes the fibronectin and allows increased retention of $\mathrm{Lp}(\mathrm{a})$. Thus, in addition to retention via the apoB moiety, $\mathrm{Lp}(\mathrm{a})$ also now associates with matrix via a second, apo(a)-mediated process. 
Alternatively, there may be yet unidentified Lp(a)-binding proteins in the matrix.

Based on our data, we hypothesize that in normal subendothelial intima the matrix proteins such as fibronectin and collagens are masked by the HSPG present in matrix (Fig. 7). This masking prevents the binding of lipoproteins and, as reported previously (29), monocytes and their subsequent retention within the intima. Our hypothesis is that agents such as lipids and endotoxins stimulate endothelial cells to secrete the matrix HSPG-degrading enzyme, heparanase. Loss of matrix HSPG at sites of injury will increase lipoprotein binding and trigger monocyte recruitment. Removal of HSPG may have additional proatherogenic consequences. These include increases in arterial permeability and release of matrix growth factors from matrix HSPG (59). The growth factors might stimulate endothelial cells to synthesize matrix proteins and induce smooth muscle cells to migrate and proliferate in the intima. Thus, we postulate that loss of HSPG is an atherosclerosis-promoting process.

\section{Acknowledgments}

These studies were supported by grants HL-21006 SCOR (I.J. Goldberg), HL-45095 (S. Pillarisetti, L. Paka, and I.J. Goldberg) and HLK14-03323 (J.C. Obunike) from the National Heart, Lung, and Blood Institute, and by a grant in aid from the American Heart Association, New York City Affiliate (S. Pilarisetti). Dr. Pillarisetti is also the recipient of an Investigator Award and Dr. Berglund an Established Investigatorship from the American Heart Association, New York City Affiliate.

\section{References}

1. Scanu, A.M., R.M. Lawn, and K. Berg. 1991. Lipoprotein (a) and atherosclerosis. Ann. Intern. Med. 115:209-218.

2. Hajjar, K.A., and R.L. Nachman. 1996. The role of lipoprotein (a) in atherogenesis and thrombogenesis. Annu. Rev. Med. 47:423-442.

3. Rhoads, G.G., G. Dahlen, K. Berg, N.E. Morton, and A.L. Dannenberg. 1986. Lipoprotein (a) as risk factor for myocardial infarction. J. Am. Med. Assoc. $256: 2540-2544$.

4. Dahlen, G.H. 1994. Lipoprotein (a) in cardiovascular disease. Atherosclerosis. 108:111-126.

5. Moliterno, D.J., R.A. Lange, R.S. Meidel, J.E. Willard, C.C. Leffert, R.D. Gerard, E. Boerwinkle, H.H. Hobbs, and L.D. Hillis. 1993. Relation of plasma $\mathrm{Lp}(\mathrm{a})$ to infarct artery patency in survivors of myocardial infarction. Circulation. 88:935-940.

6. Farrar, M., F.L. Gohme, and C.J. Albert. 1994. Coronary artery disease is associated with increased $\mathrm{Lp}(\mathrm{a})$ concentrations independent of the size of the circulating apo(a) isoforms. Arterioscler. Thromb. 14:1272-1283.

7. Rath, M., A. Neindorf, T. Reblin, M. Dietel, H.J. Krebber, and U. Beisiegel. 1989. Detection and quantification of $\mathrm{Lp}(\mathrm{a})$ in arterial wall of 107 coronary bypass patients. Atherosclerosis. 9:579-592.

8. Pepin, J.M., J.A. O'Neil, and H.F. Hoff. 1991. Quantification of apoB and apo(a) in human atherosclerotic lesions. J. Lipid Res. 32:317-327.

9. Kreuzer, J., M.B. Lloyd, D. Bok, G.M. Fless, A.M. Scanu, A.J. Lusis, and M.E. Haberland. 1994. Lp(a) displays increased accumulation compared to LDL in the murine arterial wall. Chem. Phys. Lipids. 67/68:175-190.

10. Nielsen, L.B., S. Stender, K. Kjeldsen, and B.G. Nordestgaard. 1996. Specific accumulation of $\mathrm{Lp}(\mathrm{a})$ in balloon-injured rabbit aorta in vivo. Circ. Res. 78:615-626.

11. Liu, A.C., and R.M. Lawn. 1994. Vascular interactions of Lp(a). Curr. Opin. Lipidol. 5:269-273.

12. Rouy, D., M.L. Koschinsky, V. Fleury, M.J. Chapman, and E. AnglesCano. 1992. The binding of human recombinant apo(a) and plasminogen to fibrin surfaces. Biochemistry. 31:6333-6339.

13. Van der Hoek, Y., W. Sangarar, G.P. Cote, J.P. Kastelein, and M. Koschinsky. 1994. Binding of recombinant apo(a) to extracellular matrix proteins. Arterioscler. Thromb. 14:1792-1798.

14. Bihari-Varga, M., E. Gruber, M. Rotheneder, R. Zechner, and G.M. Kostner. 1988. Interaction of $\mathrm{Lp}(\mathrm{a})$ and LDL with glycosaminoglycans from human aorta. Arteriosclerosis. E 8:851-857.
15. Wight, T.N. 1995. The extracellular matrix and atherosclerosis. Curr. Opin. Lipidol. 6:326-334.

16. Timpl, R. 1994. Proteoglycans of basement membrane. EXS. 70:123-144.

17. Wight, T.N. 1989. Cell biology of arterial proteoglycans. Arteriosclerosis. 9:1020-1026.

18. Iozzo, R., I. Cohen, S. Grassel, and A. Murdoch. 1994. The biology of perlecan: the multifaceted HSPG of basement membranes and pericellular matrices. Biochem. J. 302:625-639.

19. Hoff, H.F., and W.D. Wagner. 1986. Plasma, low density lipoprotein accumulation in aortas of hypercholesterolemic swine correlates with modifications in aortic glycosaminoglycan composition. Atherosclerosis. 61:231-236.

20. Salisbury, B.G., D.P. Hajjar, and C.R. Minick. 1985. Altered glycosaminoglycan metabolism in injured arterial wall. Exp. Mol. Pathol. 42:306-319.

21. Wagner, W.D. 1985. Proteoglycan structure and function as related to atherosclerosis. Ann. NY Acad. Sci. 454:52-68.

22. Hollmann, J., A. Schmidt, D. von Bassewitz, and E. Buddecke. 1989. Relationship of sulfated glycosaminoglycans and cholesterol content in normal and atherosclerotic human aorta. Arteriosclerosis. 9:154-158.

23. Volker, W., A. Schmidt, W. Oortmann, T. Broszey, V. Faber, and E. Buddecke. 1990. Mapping of proteoglycans in atherosclerotic lesions. Eur. Heart J. 11:29-40.

24. Heinecke, J.W., H. Rosen, and A. Chait. 1984. Iron and copper promote modification of LDL by arterial smooth muscle cells. J. Clin. Invest. 74:18901894.

25. Kosugi, H., T. Kojima, and K. Kikugawa. 1989. Thiobarbituric acid reactive substances from peroxidized lipids. Lipids. 24:873-881.

26. Shepherd, J., K. Bedford, and H.G. Morgan. 1976. Radioiodination of human low density lipoprotein: a comparison of four methods. Clin. Chim. Acta. 66:97-101.

27. Sivaram, P., M.G. Klein, and I.J. Goldberg. 1992. Identification of a heparin-releasable lipoprotein lipase binding protein from endothelial cells. J. Biol. Chem. 267:16517-16522

28. Stins, M.F., F.R. Maxfield, and I.J. Goldberg. 1992. Polarized binding of lipoprotein lipase to endothelial cells. Arterioscler. Thromb. 12:1437-1446.

29. Sivaram, P., J.C. Obunike, and I.J. Goldberg. 1995. Lysolecithin-induced alterations of subendothelial heparan sulfate proteoglycans increase monocyte binding to matrix. J. Biol. Chem. 270:29760-29765.

30. Kruth, H.S. 1985. Subendothelial accumulation of unesterified cholesterol: an early event in the development of atherosclerosis. Atherosclerosis. 57: 337-341.

31. Simionescu, N., E. Vasile, F. Lupu, G. Popescu, and M. Simionescu. 1986. Prelesional events in atherogenesis: accumulation of extracellular cholesterol rich liposomes in the arterial intima of hyperlipidemic rabbit. Am. J. Pathol. 123:1109-1125.

32. Guyton, J.R., and K.F. Klemp. 1996. Development of lipid rich core in human atherosclerosis. Arterioscler. Thromb. Vasc. Biol. 16:4-11.

33. Schwenke, D., and T.E. Carew. 1989. Initiation of atherosclerotic lesions in cholesterol-fed rabbits. II. Selective retention of LDL vs selective increase in LDL permeability in susceptible sites of arteries. Arteriosclerosis. 9: 908-913.

34. Frank, J.S., and A.M. Fogelman. 1989. Ultrastructure of the intima in WHHL and cholesterol-fed rabbit aortas prepared by ultra rapid freezing and freeze etching. J. Lipid Res. 30:967-978.

35. Nievelstein-Post, P., G. Mottino, A. Fogelman, and J.S. Frank. 1994. An ultrastructural study of lipoprotein accumulation in cardiac valves of the rabbit. Arterioscler. Thromb. 14:1151-1161.

36. Jamieson, C.G., D.C. Usher, D.J. Rader, and E. Lavi. 1995. Apo(a) deposition in atherosclerotic plaques of cerebral vessels. A potential role of endothelial cells in lesion formation. Am. J. Pathol. 147:1567-1574.

37. Ernst, S., R. Langer, C. Cooney, and R. Sasisekharan. 1995. Enzymatic degradation of glycosaminoglycans. Crit. Rev. Biochem. Mol. Biol. 30:387-444.

38. Gallis, Z., G. Sukhova, M. Lark, and P. Libby. 1994. Increased expression of matrix metalloproteases and matrix degrading activity in vulnerable regions of human atherosclerotic plaques. J. Clin. Invest. 94:2493-2503.

39. Gallis, Z., G. Sukhova, R. Kranzhofer, S. Clark, and P. Libby. 1995. Macrophage foam cells from experimental atheroma constitutively produce matrix-degrading proteinases. Proc. Natl. Acad. Sci. USA. 92:402-406.

40. Guretzki, H.J., K.D. Gerbitz, B. Olgemoller, and E. Schleicher. 1994 Atherogenic levels of LDL alter the permeability and composition of endothelial barrier. Atherosclerosis. 107:15-24.

41. Colburn, P., C.P. Dietrich, and V. Buonassisi. 1996. Alterations of heparan sulfate moieties in cultured endothelial cells exposed to endotoxin. Arch. Biochem. Biophys. 325:129-138.

42. Fisher, E.J., S.V. McLennan, D.R. Yue, and J.R. Turtle. 1994. Cell associated proteoglycans of retinal pericytes and endothelial cells. Modulation by glucose and ascorbic acid. Microvasc. Res. 48:179-189.

43. Grimm, J., R. Keller, and P.G. Groot. 1988. Laminar flow induces cell polarity and leads to rearrangement of proteoglycan metabolism in endothelial cells. Thromb. Haemostasis. 60:437-441.

44. Guretzki, H.J., E. Schleicher, K.D. Gerbitz, and B. Olgemoller. 1994. Heparin induces endothelial extracellular matrix alterations and barrier dysfunction. Am. J. Physiol. 267:C946-C954. 
45. Hennig, B., D.W. Lipke, G.A. Boissonneault, and S. Ramasamy. 1995. Role of fatty acids and eicosanoids in modulating proteoglycan metabolism in endothelial cells. Prostaglandins Leuko. Essent. Fatty Acids. 53:315-324.

46. Geller, R.L., N.S. Ihrcke, J. Maines, B.J. Lindman, and J.L. Platt. 1993. Loss of heparan sulfate as a manifestation of cellar immunity in vivo and in vitro. Transplant Proc. 25:144-145.

47. Oishi, K., R.L. Raynor, P.A. Charp, and J.F. Kuo. 1988. Regulation of protein kinase by lysophospholipids: potential role in signal transduction. $J$. Biol. Chem. 263:6865-6871.

48. Ohara, Y., T. Peterson, B. Zheng, J.F. Kuo, and D.G. Harrison. 1994. Lysophosphatidylcholine increases vascular superoxide anion production via protein kinase C activation. Arterioscler. Thromb. 14:1007-1013.

49. Watson, A.D., M. Navab, S. Hama, A. Sevanian, S.M. Prescott, D.M. Stafforini, T.M. McIntyre, A.M. Fogelman, and J.A. Berliner. 1995. Effect of platelet activating factor-acetylhydrolase on production and action of minimally oxidized LDL. J. Clin. Invest. 95:774-782.

50. Watson, A.D., J.A. Berliner, S. Hama, B.N. LaDu, K.F. Faull, A.M. Fogelman, and M. Navab. 1995. Protective effect of high density lipoprotein associated paraoxonase. Inhibition of the biological activity of minimally oxidized LDL. J. Clin. Invest. 96:2882-2891.

51. Katsuda, S., Y. Okada, T. Minamoto, Y. Oda, Y. Matsui, and I. Nakanishi. 1992. Collagens in human atherosclerosis. Immunohistochemical analysis using collagen type-specific antibodies. Arterioscler. Thromb. 12:494-502.

52. Kakolyris, S., P. Karakitosis, M. Tzardi, and E. Agapitos. 1995. Immu- nohistochemical detection of fibronectin in early and advanced atherosclerosis. In Vivo (Attiki). 9:35-40.

53. Stenman, S., K. von Smitten, and A. Vaheri. 1980. Fibronectin and atherosclerosis. Acta Med. Scand. 642(Suppl.):165-170.

54. Tanouchi, J., M. Uematsu, A. Kitabatake, T. Masuyama, H. Ito, Y. Doi, M. Inoue, and T. Kamada. 1992. Sequential appearance of fibronectin, collagen and elastin during fatty streak initiation and maturation in hypercholesterolemic fat-fed rabbits. Jpn. Circ. J. 56:649-656.

55. Hynes, R.O., and K.M. Yamada. 1982. Fibronectins: multifunctional modular glycoproteins. J. Cell Biol. 95:369-377.

56. Salonen, E.M., M. Jauhianen, L. Zardi, A. Vaheri, and C. Ehnholm. 1989. Lp(a) binds to fibronectin and has serine protease activity capable of cleaving it. EMBO (Eur. Mol. Biol. Org.) J. 8:4035-4040.

57. Moser, T.M., J. Enghild, S. Pizzo, and M.S. Stack. 1993. The extracellular proteins laminin and fibronectin contain binding domains for plasminogen and tissue plasminogen activator. J. Biol. Chem. 268:18917-18923.

58. Skubitz, A.P., J.B. McCarthy, A.S. Charonis, and L.C. Furcht. 1988. Localization of three distinct heparin binding domains of laminin by monoclonal antibodies. J. Biol. Chem. 263:4861-4868.

59. Vlodavsky, I., H. Miao, B. Medalion, P. Danagher, and D. Ron. 1996. Involvement of heparan sulfate and related molecules in sequestration and growth promoting activity of fibroblast growth factor. Cancer Metastasis. Rev. 15:177-186. 